\title{
IDENTIFIKASI RISIKO PADA PRODUKSI PAPRIKA (STUDI KASUS DI CV CANTIGI KABUPATEN GARUT, JAWA BARAT)
}

\author{
Febrica Handryani1), Sulistyodewi Nur Wiyono2), Kuswarini Kusno3), \\ dan Dini Rochdiani ${ }^{4)}$ \\ 1,2,3,4)Program Studi Agribisnis, Fakultas Pertanian Universitas Padjadjaran \\ Jl.. Raya Bandung Sumedang KM.21, Kec. Jatinangor, Kab. Sumedang Jawa Barat, Indonesia \\ e-mail: 1)febricahandryani45@gmail.com
}

(Diterima 24 Januari 2020 / Revisi 17 Februari 2020 / Disetujui 24 Maret 2020)

\begin{abstract}
Paprika is one of the leading commodities of horticulture in the provinces of West Java. West Java is the largest contributors to the national paprika in Indonesia, this leads to support the community welfare and regional development there. One of an area in West Java Province that produces paprika is CV Cantigi at Cikandang village of Garut Regency. CV Cantigi produces a variety of horticultural crops, but the main commodity is paprika. Every period CV Cantigi experienced various risk events in paprika production, thus making the productivity decrease. The purpose of this study is to identify the risks that occur in paprika production in CV Cantigi and determine the mitigation actions to minimize the risks that arise. This research uses descriptive qualitative method with the house of the risk analysis tool. The results showed that 25 risk events occurred in the process of paprika production in CV Cantigi. There are 3 mitigation actions for paprika production that is producing paprika plants under the shade because paprika plants need optimal temperatures to grow, making a planting calendar to determine when the right time to produce paprika, and making observations before pest control so that there is no wrong target with mitigation actions then it can be minimized or reducing the emergence of priority risk agents.
\end{abstract}

Keywords: CV Cantigi, house of risk, identification of production risks, mitigation action, paprika

\begin{abstract}
ABSTRAK
Paprika merupakan salah satu komoditas unggulan hortikultura di Provinsi Jawa Barat serta Jawa Barat menjadi penyumbang paprika nasional terbesar di Indonesia dengan ini dapat menunjang kesejahteraan masyarakat dan pembangunan daerah. Salah satu daerah di Provinsi Jawa Barat yang memproduksi paprika yaitu CV Cantigi pada desa Cikandang Kabupaten Garut. CV Cantigi memproduksi berbagai komoditas tanaman hortikultura namun yang menjadi komoditas utamanya yaitu tanaman paprika. Setiap periode CV Cantigi mengalami berbagai kejadian risiko pada bagian produksi, sehingga menyebabkan penurunan produktivitas. Tujuan dari penelitian ini adalah untuk mengidentifikasi risikorisiko yang terjadi pada produksi paprika di CV Cantigi, dan menentukan aksi mitigasi agar dapat meminimalisi risiko-risiko yang muncul tersebut. Penelitian ini menggunakan metode kualitatif deskriptif dengan alat analisis house of risk. Hasil penelitian menunjukkan bahwa terdapat 25 peristiwa risiko yang terjadi pada proses produksi paprika di CV Cantigi. Terdapat 3 aksi mitigasi produksi paprika yaitu memproduksi tanaman paprika di bawah naungan karena tanaman paprika membutuhkan suhu yang optimal untuk tumbuh, membuat kalender tanam untuk menentukan kapan waktu yang tepat untuk memproduksi paprika, dan melakukan pengamatan sebelum pengendalian OPT agar tidak terjadi salah sasaran dengan adanya aksi mitigasi maka dapat meminimalisasi atau menurunkan munculnya sumber risiko prioritas.
\end{abstract}

Kata kunci: aksi mitigasi, CV Cantigi, house of risk, identifikasi risiko roduksi, paprika

\section{PENDAHULUAN}

Indonesia merupakan negara agraris yang dapat menjadikan sektor pertanian sebagai sumber mata pencaharian yang utama. Menurut data
Badan Pusat Statistika (BPS) pada tahun 2018 sebesar 88,27 \% penduduk Indonesia bermata pencaharian pada sektor pertanian. Sektor pertanian terdiri dari beberapa subsektor diantaranya yaitu subsektor pangan, hortikultura, dan 
perkebunan. Subsektor hortikultura merupakan salah satu subsektor pertanian yang mengalami perkembangan setiap tahunnya diantaranya sayuran, buah-buahan, tanaman hias, dan tanaman obat-obatan. Menurut data Statistik Tanaman Sayuran dan Buah-buahan Semusim Indonesia pada Tahun 2017 sayuran mengalami peningkatan setiap tahunnya bisa dilihat pada Tabel 1 karena bernilai ekonomis yang cukup tinggi. Sayuran memiliki kontribusi cukup besar terhadap peningkatan pendapatan dan kesejahteraan masyarakat.

Menurut data Statistik Tanaman Sayuran dan Buah-buahan Semusim Indonesia 2017 paprika merupakan salah satu komoditas yang baik untuk terus dikembangkan, karena paprika memiliki pertumbuhan tertinggi dibandingkan dengan sayuran lain dan juga paprika termasuk golongan sayuran exlusive dan bernilai ekonomis (Savaringga, 2013).

Paprika (Capsicum annum var. Grossum) merupakan tanaman sayuran yang relatif baru dikenal di Indonesia, yaitu sejak tahun 1990-an. Pada umumnya paprika digunakan sebagai bahan penyedap atau bahan masakan yang berasal dari luar negeri. Tanaman paprika berasal dari Amerika Tengah dan Amerika Selatan dimana banyak spesies telah dibudidayakan beratus tahun sebelum Columbus mendarat di benua tersebut (Alberta 2004; Wien 1997 dikutip T.K. Moekasan, dkk., 2008). Di Amerika paprika juga digunakan sebagai bahan pewarna makanan. Zat kapsaisin (C9H12O2) yang biasanya terdapat pada buah cabai tidak terkandung dalam paprika sehingga rasa paprika tidak terasa pedas, bahkan cenderung manis. Oleh karena itu paprika disebut juga cabai manis.

Menurut Harpenas, dkk., (2010) paprika umumnya ditanam pada daerah dataran tinggi dengan ketinggian 750 mdpl. Temperatur yang optimal untuk pertumbuhan dan perkembangan paprika antara 21-250 C. Sedangkan untuk pembentukan buah paprika memerlukan suhu 15$18^{\circ}$ C. Paprika merupakan tanaman semusim yang dapat tumbuh di daerah dataran tinggi, paprika dibedakan menurut bentuk, warna, dan ukuran. Berdasarkan bentuknya paprika dibagi menjadi dua bentuk, yaitu berbentuk lonceng dan berbentuk lonjong (Hadinata, 2004) tergantung varietasnya.

Menurut Statistik Tanaman Sayuran dan Buah-buahan Semusim Indonesia 2017 di Indonesia terdapat beberapa daerah yang cocok untuk memproduksi tanaman paprika seperti Jawa Barat, Jawa Timur, Bali, Nusa Tenggara Barat, Papua karena tanaman paprika dapat dikembang-

Tabel 1. Perkembangan Produksi Tanaman Sayuran Menurut Jenis Tanaman Tahun 2016-2017

\begin{tabular}{clcccc}
\hline No & Jenis Tanaman & $\begin{array}{c}\text { Tahun 2016 } \\
\text { (Ton) }\end{array}$ & $\begin{array}{c}\text { Tahun 2017 } \\
\text { (Ton) }\end{array}$ & $\begin{array}{c}\text { Pertumbuhan } \\
\text { (Growth) Absolut }\end{array}$ & \% \\
\hline 1. & Buncis & 275.512 & 279.041 & 3.529 & 1,28 \\
2. & Kembang kol & 142.842 & 152.869 & 10.027 & 7,01 \\
3. & Paprika & 5.257 & 7.391 & 2.134 & 40,59 \\
\hline
\end{tabular}

Sumber: Statistik Tanaman Sayuran dan Buah-buahan Semusim Indonesia, 2017

Tabel 2. Produksi, Luas Panen, dan Hasil Per Hektar Paprika, 2017

\begin{tabular}{lccc}
\hline \multicolumn{1}{c}{ Provinsi } & $\begin{array}{c}\text { Produksi Januari- } \\
\text { Desember (Ton) }\end{array}$ & $\begin{array}{c}\text { Luas Panen } \\
\text { Januari-Desember } \\
\text { (Ha) }\end{array}$ & $\begin{array}{c}\text { Hasil Per Hektar } \\
\text { (Ton/Ha) }\end{array}$ \\
\hline Riau & 3 & 6 & 0,5 \\
Jawa Barat & 5.104 & 177 & 28,84 \\
Jawa Tengah & 4 & 1 & 4,00 \\
Jawa Timur & 2.038 & 31 & 65,74 \\
Banten & 3 & 3 & 1,00 \\
Bali & 217 & 24 & 9,04 \\
Nusa Tenggara Barat & 9 & 1 & 9,00 \\
Nusa Tenggara Timur & 3 & 3 & 1,00 \\
Sulawesi Utara & 1 & 4 & 0,25 \\
Papua & 9 & 4 & 0,25 \\
\hline
\end{tabular}

Sumber: Statistik Tanaman Sayuran dan Buah-buahan Semusim Indonesia, 2017 
Tabel 3. Produksi Paprika Kelompok Tani di Kabupaten Garut, 2018

\begin{tabular}{llcc}
\hline \multicolumn{1}{c}{ No } & \multicolumn{1}{c}{ Ketua } & Luasan (Ha) & Rata-rata produk/Ha \\
\hline 1. Hade Farm & Dedin M. & 3 & 100 ton \\
2. Cantigi & Ir. Iyep R. Winaya & 1 & 75 ton \\
\hline
\end{tabular}

Sumber : Kelompok Tani Cantigi, 2018

kan pada daerah dataran tinggi. Provinsi Jawa Barat merupakan penyumbang terbesar produksi paprika nasional. Salah satunya CV Cantigi yang merupakan sentra produksi paprika di daerah Cikandang Kabupaten Garut Jawa Barat.

CV Cantigi memproduksi berbagai jenis paprika yaitu paprika hijau, merah, kuning dan orange dengan harga jual yang berbeda-beda. Paprika dengan harga yang paling tinggi yaitu paprika orange sedangkan yang paling rendah yaitu paprika hijau. Pangsa pasar dari CV Cantigi ini yaitu pasar konvensional dan supermarket. CV Cantigi masih belum mampu memenuhi kebutuhan pasar dalam negeri karena jumlah produksi yang belum maksimal salah satu faktor penyebabnya yaitu adanya risiko-risiko yang terjadi ketika proses produksi seperti tanaman terkena hama dan penyakit, cuaca yang tidak menentu sehingga menghambat proses produksi dan dapat menurunkan produktivitas. Prabaningrum et al. (2002), menyatakan bahwa petani melakukan penyemprotan pestisida secara rutin sebagai upaya pencegahan serangan OPT tetapi hasilnya tidak memuaskan serta memberikan dampak negatif terhadap buah.

Mound (2002) melaporkan bahwa trips Frankliniella occidentalis merupakan hama utama pada tanaman paprika. Hama trips selain menimbulkan kerusakan pada tanaman juga berperan sebagai vektor penyakit virus TSWV (tomato spotted wilt virus). Rooejen et al. (1998) dalam Kurk 162 (2002) menyatakan bahwa serangan TSWV yang ditularkan oleh trips F. Occidentalis mampu mengakibatkan kerusakan pada tanaman yang sangat nyata pada tanaman paprika di Netherlands. Murai (2002) mengatakan bahwa di Jepang, spesies trips yang secara ekonomi dapat merugikan tanaman paprika adalah Thrips palmi. Hama trips biasanya lebih banyak menyerang pada musim kemarau. Kelembaban yang rendah dan suhu yang tinggi pada musim kemarau cocok bagi hama trips sehingga perkembangbiakannya lebih cepat (Sunjaya, 1970). Daerah barat daya
Florida, Amerika Serikat kerugian finansial akibat serangan trips mencapai lebih dari 10 juta dolar Amerika (Frantz et al. 1995).

Oleh sebab itu, identifikasi risiko sangat diperlukan untuk meminimalisasi tingkat risiko dan dampak dari risiko tersebut (Hanafi, 2006). Penelitian ini bertujuan untuk :

1. Mengidentifikasi risiko pada produksi paprika di CV Cantigi Cikajang, Garut.

2. Mengetahui aksi mitigasi yang dapat dilakukan untuk menanggani risiko yang terjadi pada produksi paprika di CV Cantigi Cikajang, Garut.

\section{METODE}

\section{LOKASI DAN WAKTU}

Penelitian ini dilakukan di CV Cantigi Desa Cikandang Kabupaten Garut pada bulan November 2019, karena CV Cantigi merupakan salah satu perusahaan yang aktif dalam kegiatan usahatani dan juga berdasarkan letak geografisnya yang cocok dengan syarat tumbuh tanaman paprika. CV Cantigi memiliki 10 screenhouse dan memiliki 15 orang tenaga kerja. Jenis penelitian yang digunakan yaitu kualitatif dalam bentuk studi kasus dengan variabel yaitu proses budidaya paprika, risiko yang terjadi selama budidaya, sumber dari risiko tersebut, dan aksi mitigasi yang dilakukan dalam menanggani risiko yang terjadi. Analisis yang digunakan dalam penelitian ini adalah analisis deskriptif dengan metode House of Risk (HOR).

\section{METODE ANALISIS DATA}

Analisis deskriptif digunakan untuk mengidentifikasi risiko yang terjadi dalam produksi paprika di CV Cantigi. Metode HOR yaitu modifikasi antara model Failure Mode dan Effects Analysis (FMEA) yang digunakan untuk pengukuran risiko secara kuantifikasi dan model House of Quality (HOQ) digunakan untuk memprioritaskan sumber risiko yang harus ditangani terlebih dahulu dan untuk memilih tindakan yang paling efektif agar dapat mengurangi risiko potensial yang ditimbul- 
kan oleh sumber risiko (Geraldin, 2007; Pujawan, 2005). Pada penelitian ini, analisis risiko dengan menggunakan metode HOR dibagi menjadi dua fase, yaitu fase identifikasi risiko (risk identification) dan fase strategi proaktif. Output dari HOR fase 1 akan digunakan sebagai input pada fase 2 . Dari fase pertama HOR, akan didapatkan nilai prioritas risiko dan level risiko dari masingmasing sumber risiko yang telah teridentifikasi. Sumber risiko dengan level risiko tinggi akan menjadi input data pada tahap 1 dari HOR fase ke- 2 .

House of Risk 1 digunakan untuk menentukan sumber risiko yang akan menjadi prioritas agar dapat dilakukan tindakan pencegahan. Tahapan dalam metode HOR 1 antara lain :

1. Identifikasi kejadian risiko (risk event) dengan mengidentifikasi kejadian yang mungkin akan terjadi pada proses kegiatan budidaya.

2. Identifikasi tingkat keparahan dampak (severity) pada setiap kejadian risiko (risk event). Dengan menggunakan skala severity yang menyatakan besar gangguan ditimbulkan oleh suatu kejadian risiko terhadap proses bisnis pelaku. Dalam tahap ini menggunakan skala 1-10, di mana skala 10 menunjukkan kejadian risiko yang sangat ekstrem.

3. Mengidentifikasi sumber risiko (source of risk) dan memberikan penilaian terhadap kemungkinan terjadinya (occurrence). Penilaian untuk sumber risiko dilakukan dengan memberikan nilai 1-10 sesuai dengan tingkat kemungkinan kejadiannya. Semakin kecil nilai yang diberikan berarti source of risk tersebut hampir tidak pernah terjadi.

4. Mengembangkan matriks korelasi antara source of risk dan risk event. Masing-masing kolom dalam matriks korelasi diberikan nilai $\{0,1,3,9\}$ di mana 0 (nol) menunjukkan tidak adanya korelasi sedangkan 1,3, dan 9 menunjukkan tingkat korelasi rendah, sedang, dan tinggi.

Tabel 4. Skala Severity

\begin{tabular}{|c|c|c|}
\hline Severity & Level & Kriteria \\
\hline No & 1 & Tidak ada efek \\
\hline Very slight & 2 & Petani tidak terganggu. Sangat sedikit efek pada produk atau sistem \\
\hline Slight & 3 & Petani sedikit terganggu. Sedikit efek pada produk atau sistem \\
\hline Minor & 4 & Petani mengalami gangguan kecil. Sedikit efek pada produk atau sistem \\
\hline Moderate & 5 & $\begin{array}{l}\text { Petani mengalami beberapa ketidakpuasan. Efek sedang pada produk atau } \\
\text { sistem }\end{array}$ \\
\hline Significant & 6 & $\begin{array}{l}\text { Petani mengalami ketidaknyamanan. Kondisi produk rusak tetapi masih } \\
\text { beroperasi dengan aman. Gagal sebagian namun masih beroperasi }\end{array}$ \\
\hline Major & 7 & $\begin{array}{l}\text { Petani tidak puas. Kondisi produk sangat terpengaruh tetapi masih berfungsi } \\
\text { dan aman. Sistem terganggu }\end{array}$ \\
\hline Extreme & 8 & Petani sangat tidak puas \\
\hline Serious & 9 & Potensi efek berbahaya \\
\hline Hazardous & 10 & Efek berbahaya \\
\hline
\end{tabular}

Tabel 5. Skala Occurrence

\begin{tabular}{lcl}
\hline \multicolumn{1}{c}{ Occurrence } & Level & \multicolumn{1}{c}{ Kriteria } \\
\hline Almost never & 1 & Sejarah menunjukkan tidak pernah ada kegagalan \\
Remote & 2 & Kemungkinan kegagalan langka \\
Vert slight & 3 & Kemungkinan kegagalan sangat sedikit \\
Slight & 4 & Kemungkinan kegagalan beberapa \\
Low & 5 & Kemungkinan kegagalan sesekali \\
Medium & 6 & Kemungkinan kegagalan sedang \\
Moderately high & 7 & Kemungkinan kegagalan yang cukup tinggi \\
High & 8 & Kemungkinan kegagalan tinggi \\
Very high & 9 & Kemungkinan kegagalan sangat tinggi \\
Almost certain & 10 & Kegagalan pasti terjadi. Kegagalan pernah terjadi sebelumnya
\end{tabular}


5. Menghitung nilai Aggregate risk potential (ARPj) untuk masing-masing source of risk dengan mengunakan rumus :

$$
A R P_{j}=O_{j} \sum S_{i} R_{i j} \ldots(1)
$$

Keterangan :

$A R P_{j}=$ Agen Potensial Risiko Agregat

$O_{j} \quad=$ Peluang terjadinya risiko

$S_{i} \quad=$ Dampak kejadian risiko

$R i_{j} \quad=$ Tingkat keterhubungan antara sumber risiko dengan kejadian risiko (korelasi).

Kemudian keseluruhan hasil di atas disajikan dalam satu tabel agar dapat mengefisienkan dalam proses perhitungan (Tabel 6).

Selanjutnya menganalisis House of Risk 2, untuk menentukan penangganan yang harus diselesaikan terlebih dahulu. Perusahaan harus memilih aksi penanganan yang ideal, artinya aksi yang tingkat kesulitannya rendah jika dilakukan namun akan efektif dalam mengurangi kemungkinan terjadinya agen atau sumber risiko.

Tahap-tahap dalam HOR 2 antara lain :

1. Memilih nomor sumber risiko dengan tingkat prioritas tinggi, menggunakan diagram Pareto untuk mnganalisis ARPj. Menurut Dermawan (2006), analisis pareto merupakan teknik yang mempermudah pengambilan keputusan dalam mengidentifikasi masalah yang utama untuk diselesaikan. Aplikasi hukum pareto pada risiko yaitu $80 \%$ kerugian disebabkan oleh $20 \%$ risiko yang krusial. Apabila 20\% risiko krusial dapat diatasi maka perusahaan dapat menghindari 80\% kerugian (Kountur, 2008). Kemudian diajadikan input pada HOR 2.

2. Mengidentifikasi aksi mitigasi yang dianggap berkolerasi untuk mencegah sumber risiko. Satu sumber risiko dapat mengakibatkan lebih dari satu aksi dan satu aksi dapat mengurangi kemungkinan munculnya lebih dari satu sumber risiko.

3. Menentukan hubungan antara aksi pencegahan dengan setiap sumber risiko. $E j_{k}$ bernilai antara $(0,1,3,9)$ di mana 0 berarti tidak ada korelasi, 1 berarti tingkat korelasi rendah, 3 berarti tingkat korelasi sedang, 9 berarti tingkat korelasi tinggi antara aksi (k) dan sumber risiko (j). Hubungan $E j_{k}$ dianggap sebagai derajat keefektifan dari aksi (k) dalam meminimalisir kemungkinan munculnya sumber risiko (j).

4. Menghitung soal keefektifan dari setiap aksi, menggunakan :

$$
\mathrm{TE}=E j_{k} \times A R P_{k} \ldots(2)
$$

\begin{tabular}{|c|c|c|c|c|c|}
\hline \multirow{2}{*}{ Business Processes } & \multirow{2}{*}{$\begin{array}{c}\text { Risk } \\
\text { Event/E }\end{array}$} & \multicolumn{3}{|c|}{ Source of Risk/A $\mathbf{A}_{\mathbf{j}}$} & \multirow{2}{*}{$\begin{array}{c}\text { Severity of risk } \\
\text { event } / S_{i}\end{array}$} \\
\hline & & $\mathrm{A}_{1}$ & $\mathrm{~A}_{2}$ & $\mathrm{~A}_{3}$ & \\
\hline Plan & $\mathrm{E}_{1}$ & $\mathrm{R}_{11}$ & $\mathrm{R}_{12}$ & $\mathrm{R}_{23}$ & $\mathrm{~S}_{1}$ \\
\hline Source & $\mathrm{E}_{2}$ & $\mathrm{R}_{21}$ & $\mathrm{R}_{22}$ & & $\mathrm{~S}_{2}$ \\
\hline Make & $\mathrm{E}_{3}$ & $\mathrm{R}_{31}$ & & & $\mathrm{~S}_{3}$ \\
\hline Deliver & $\mathrm{E}_{4}$ & $\mathrm{R}_{41}$ & & & $\mathrm{~S}_{4}$ \\
\hline Return & $\mathrm{E}_{5}$ & & & & $\mathrm{~S}_{5}$ \\
\hline Occurrence of agent j & & $\mathrm{O}_{1}$ & $\mathrm{O}_{2}$ & $\mathrm{O}_{3}$ & \\
\hline Aggregate risk potential $\mathrm{j}$ & & $\mathrm{ARP}_{1}$ & $\mathrm{ARP}_{2}$ & $\mathrm{ARP}_{3}$ & \\
\hline Priority rank of agent $\mathrm{j}$ & & & & & \\
\hline
\end{tabular}

Tabel 6. Model HOR Fase 1

Sumber : Pujawan dan Geraldin (2009)

Tabel 7. Kategori Nilai Kesulitan Dalam Melakukan Mitigasi

\begin{tabular}{ccc}
\hline No & $\begin{array}{c}\text { Kategori Nilai } \\
\text { Kesulitan }\end{array}$ & Makna Kategori Nilai Kesulitan \\
\hline 1 & 3 & $\begin{array}{l}\text { (Low) dalam melaksanakan mitigasi, biaya yang dikeluarkan dirasa } \\
\text { cukup terjangkau dan tidak terlalu sulit dilaksanakan. } \\
\text { (Medium) dalam melaksanakan mitigasi, biaya yang dikeluarkan } \\
\text { dirasa cukup tinggi dan cukup sulit dilaksanakan } \\
\text { (High) dalam melaksanakan mitigasi, biaya yang dikeluarkan } \\
\text { dirasa tinggi dan sulit dilaksanakan. }\end{array}$ \\
\hline
\end{tabular}

Sumber : Pujawan dan Geraldin (2009) 
Tabel 8. House of Risk 2

\begin{tabular}{|c|c|c|c|c|}
\hline \multirow{2}{*}{ To be treated risk source $/ \mathbf{A}_{\mathbf{j}}$} & \multicolumn{3}{|c|}{ Preventive action / $\mathbf{P A}_{K}$} & \multirow{2}{*}{$\begin{array}{l}\text { Aggregate risk } \\
\text { potential/ARP }\end{array}$} \\
\hline & $\mathbf{P A}_{1}$ & $\mathbf{P A}_{2}$ & $\mathbf{P A}_{3}$ & \\
\hline $\mathrm{A}_{1}$ & $E_{11}$ & $\mathrm{E}_{12}$ & $\mathrm{E}_{23}$ & $\mathrm{ARP}_{1}$ \\
\hline $\mathrm{A}_{2}$ & $\mathrm{E}_{21}$ & $\mathrm{E}_{22}$ & & $\mathrm{ARP}_{2}$ \\
\hline $\mathrm{A}_{3}$ & $\mathrm{E}_{31}$ & & & $\mathrm{ARP}_{3}$ \\
\hline $\mathrm{A}_{4}$ & $\mathrm{E}_{41}$ & & & $\mathrm{ARP}_{4}$ \\
\hline Total effectiveness of action $k\left(\mathrm{TE}_{\mathrm{k}}\right)$ & $\mathrm{TE}_{1}$ & $\mathrm{TE}_{2}$ & $\mathrm{TE}_{3}$ & \\
\hline Degree if difficulty performing action $k\left(\mathrm{D}_{\mathrm{k}}\right)$ & $\mathrm{D}_{1}$ & $\mathrm{D}_{2}$ & $\mathrm{D}_{3}$ & \\
\hline Effectiveness to difficulty ratio $k\left(\mathrm{ETD}_{\mathrm{k}}\right)$ & $\mathrm{ETD}_{1}$ & $\mathrm{ETD}_{2}$ & $\mathrm{ETD}_{3}$ & \\
\hline Rank of priority & $\mathrm{R}_{1}$ & $\mathrm{R}_{2}$ & $\mathrm{R}_{3}$ & \\
\hline
\end{tabular}

Sumber : Pujawan dan Geraldin (2009)

Keterangan:

$S_{i} \quad$ : Tingkat dampak suatu risiko (severity level of risk)

$O_{j} \quad$ : Tingkat kemunculan (occurrence) risk agent

$R i_{j} \quad$ : Hubungan korelasi risk event $\mathrm{i}$ dengan risk agent $\mathrm{j}$

$A R P_{J}$ : Aggregate Risk Potentials dari risk agent $\mathrm{j}$

$A R P_{j}:$ Nilai efektifitas dari setiap tindakan mitigasi $\mathrm{k}$

$E j_{k} \quad$ : Hubungan korelasi risk agent $\mathrm{j}$ dan mitigasi risiko $\mathrm{k}$

$\mathrm{ETD}_{\mathrm{k}}$ : Effectiveness to difficulty ratio

$\mathrm{TE}_{\mathrm{k}} \quad$ : Total effectiveness of action $k a$

$\mathrm{D}_{\mathrm{k}} \quad$ : Degree of difficulty performing action

5. Memberikan penilaian terhadap tingkat derajat kesulitan dalam setiap aksi, Dk, dan menempatkan nilai tepat di bawah nilai TE (Total Efektifitas). Derajat kesulitan ditunjukkan dari skala (skala likert) yang menggambarkan data dan sumber data lain yang diperlukan dalam melakukan aksi tersebut. Menurut Pujawan dan Geraldine (2009), kesulitan dibagi menjadi 3 kategori yakni rendah dengan skor 3, sedang dengan skor 4, dan tinggi dengan skor 5 (Tabel 7).

6. Menghitung rasio antara total keefektifan dengan kesulitan menggunakan rumus:

$$
\mathrm{ETD}_{\mathrm{k}}=\mathrm{TE}_{\mathrm{k}} / \mathrm{D}_{\mathrm{k}} \ldots(3)
$$

Keterangan:

$$
\begin{aligned}
\text { ETD }_{\mathrm{k}}= & \text { Rasio antara total keefektifan dan } \\
& \text { kesulitan } \\
\mathrm{TE}_{\mathrm{k}}= & \text { Total keefektifan } \\
\mathrm{D}_{\mathrm{k}}= & \text { Tingkat Kesulitan }
\end{aligned}
$$

7. Mengurutkan prioritas untuk setiap aksi $\left(E_{k}\right)$ di mana urutan 1 merupakan urutan dengan nilai rasio total keefektifan dan kesulitan tertinggi $\left(\mathrm{ETD}_{\mathrm{k}}\right)$.

\section{HASIL DAN PEMBAHASAN}

Salah satu desa yang menjadi wilayah produksi tanaman hortikultura terbesar di Kabupaten Garut ialah Desa Cikandang dengan luas lahan sebesar 1.756.000 ha. Desa Cikandang termasuk kedalam wilayah dataran tinggi dengan ketinggian wilayah 1.310 meter dari atas permukaan laut dengan suhu udara $19-26^{\circ} \mathrm{C}$ sehingga cocok untuk wilayah pertanian, perkebunan dan perternakan. CV Cantigi merupakan salah satu perusahaan agribisnis dengan berbagai komoditas tanaman hortikultura namun yang menjadi komoditas unggulan yaitu tanaman paprika. CV Cantigi berdiri pada tahun 1998. Budidaya dilakukan secara konvensional dan screen house. Komoditas pada lahan konvensional diantaranya yaitu tomat, cabai keriting, head lettuce, wortel, kubis, selada, seledri, dan kentang. Sementara komoditas di screen house yaitu paprika, tomat cherry, mentimun jepang/kyuri. Luas lahan konvensional yaitu 2,5 hektar dan luas screen house yaitu $6.480 \mathrm{~m}^{2}$.

Dalam menjalankan usahanya, CV Cantigi menjalin kerja sama dengan beberapa supplier yang diantaranya ialah PT. Saung Mirwan (Bogor), PT. Alamanda, PT. Bimandiri, Amazing, PT. Lumbung Padi dan lain sebagainya. Semakin meningkatnya permintaan akan pasokan sayuran dari mitra-mitra tersebut, maka CV Cantigi berusaha meningkatkan skala usaha guna memenuhi permintaan. Proses budidaya tanaman paprika pada CV Cantigi :

\section{Persiapan Lahan}

Persiapan lahan dilakukan untuk mensterilkan screen house, instalasi irigasi serta media agar 
dapat menonaktifkan virus yang ada di screen house serta membersihkan instalasi nutrisi selama alat irigasi dipakai pada periode pertama. Larutan yang digunakan untuk sterilisasi adalah kalium klorida atau larutan KNO3.

2. Pembuatan Media Tanam

Pembuatan media tanam berupa pengisian polybag slab menggunakan arang sekam dan pemasangan polybag pada lahan disesuaikan dengan jumlah barisan dan jarak dalam barisan, jarak antar barisan antara 110-120 cm dan jarak dalam barisan antara 35-40 cm. Setelah polybag slab terpasang, dilakukan pembuatan lubang tanam dengan diameter 5$8 \mathrm{~cm}$ atau disesuaikan dengan diameter polybag semai.

3. Persemaian Benih

Benih paprika disemai menggunakan baki tray yang telah diisi media arang sekam dengan kedalaman lubang benih 2-3 cm. Lalu benih dimasukkan ke lubang tanam dengan 2 benih per lubang. Kemudian ditutup dengan arang sekam setelah itu disiram sampai kapasitas titik jenuh air dan ditutup menggunakan kain/karung untuk menjaga kelembaban pada proses perkecambahan. Selama di persemaian dilakukan pemberian nutrisi dan pestisida secara rutin untuk pemenuhan kebutuhan unsur hara serta mencegah terjadinya serangan hama dan penyakit.

4. Penanaman

Seblum bibit ditanam, terlebih dahulu melakukan proses aklimatisasi selama 2-3 hari dengan tujuan penyesuaian tanaman terhadap iklim dan lingkungan baru. Kemudian melakukan penyiraman pada polybag slab sebanyak 12 liter/polybag dengan tujuan agar media mempunyai unsur hara dan terjaga kelembabannya. Penanaman dilakukan pada siang hari ataupun sore hari.

5. Penyiraman Aplikasi Nutrisi

Penyiraman dilakukan untuk memenuhi kebutuhan air pada tanaman sehingga dapat tumbuh dan menjaga kelembaban dikarenakan enzim dalam media menjadi aktif serta unsur hara terserap dengan baik agar proses fotosintetis berjalan dengan optimal. Pembuatan air nutrisi yaitu mencampurkan air sebanyak 1000 liter dengan larutan nutrisi A dan nutrisi B yang masing-masing sebanyak 5 liter dengan sistem irigasi tetes. Penyiraman dilakukan tergantung musim dan dapat dilakukan dengan interval 2-4 kali. Rata-rata jumlah larutan per aplikasi sebanyak 50-200 ml per tanaman.

6. Pengendalian Hama Penyakit

Pengendalian hama penyakit pada budidaya paprika di screen house biasanya dengan pemasangan yellow trap atau dilakukan pengendalian hama terpadu dari mulai kultur teknis hingga terakhir melakukan pengendalian dengan kimiawi.

7. Pemasangan Tali

Pemasangan tali bertujuan untuk menopang tanaman agar tanaman tumbuh tegak lurus ke atas, sehingga tidak mudah rebah. Pemasangan tali ini juga dikarenakan tanaman yang dibudidayakan adalah tanaman indeterminate yang sifatnya mempunyai laju pertumbuhan yang terus bertumbah. Pemasangan tali dilakukan setelah tanam dengan dua buah tali per satu pohon.

8. Pelilitan

Pelilitan bertujuan untuk menopang tanaman agar tidak roboh. Pelilitan dilakukan pada tanaman saat berumur 55-60 HST dengan interval 4-5 hari. Pelilitan dilakukan dengan cara melilitkan tali ke batang tanaman searah jarum jam.

9. Seleksi Cabang

Seleksi cabang bertujuan untuk memilih cabang yang baik, dilihat dari tinggi tanaman maupun besar batang sehingga pertumbuhannya seragam. Cabang yang dipelihara sebanyak dua cabang. Sedangkan cabang lain dilakukan topping (pemberhentian titik tumbuh). Seleksi cabang dilakukan pada saat tanaman berumur 2-3 MST. Dengan adanya seleksi cabang maka unsur hara akan terfokus pada dua cabang, sehingga dapat menghasilkan buah yang sesuai dengan kriteria yang diinginkan.

10. Pewiwilan

Pewiwilan dilakukan dengan cara membuang tunas air dan memangkas pucuk samping serta membuang mahkota bunga yang sudah layu. Pewiwilan dilakukan dengan interval 7-11 hari. 


\section{Seleksi Buah}

Seleksi buah bertujuan untuk membatasi dan memilih buah yang baik dari segi bentuk, ukuran, dan tingkat kemulusan sehingga diperoleh buah yang berkualitas baik. Seleksi buah di screen house biasanya dilakukan pada tanaman berumur 60-65 HST.

12. Panen

Panen pada tanaman paprika dilakukan dengan 2 jenis warna disesuaikan dengan permintaan pasar. Panen hijau dilakukan pada saat tanaman berumur 8-10 MST sedangkan panen warna dilakukan pada saat tanaman berumur 10-12 MST. Kriteria umum panen adalah daging buah keras dan tebal, warna buah merata diangka $80 \%$ serta bebas dari patogen. Pemanenan dilakukan dengan pisau atau cutter. Selama pertumbuhan, interval panen diangka 3-4 hari sekali selama satu kali masa produksi. Perlakuan setelah panen adalah pengolesan fungisida pada tangkai bekas panen terutama pada waktu suhu ruangan rendah dan tingkat kelembaban tinggi yang bertujuan untuk mencegah infeksi akibat bekas luka panen.

\section{Analisis House of Risk (HOR) Tahap $1 \mathrm{di}$ Tingkat Produksi}

Pada tahapan produksi paprika yang dilakukan oleh petani di CV Cantigi Desa Cikadang Kabupaten Garut, dapat diidentifikasi 25 kejadian risiko yang mungkin terjadi. Kejadian-kejadian risiko tersebut dapat teridentifikasi berkat diskusi dan wawancara dengan para petani yang memproduksi paprika. Seluruh kejadian risiko produksi paprika dapat dilihat pada Tabel 9.

Berdasarkan tabel, dampak paling besar yang dirasakan oleh petani dalam produksi paprika yaitu tanaman terserang hama (E10). Hama hampir menyerang pada setiap periode

Tabel 9. Daftar Kejadian Risiko Paprika

\begin{tabular}{|c|c|c|c|}
\hline $\begin{array}{l}\text { Tahapan } \\
\text { Produksi }\end{array}$ & Kejadian Risiko (Risk Event) & Kode & $\begin{array}{l}\text { Keparahan } \\
\text { Dampak (S) }\end{array}$ \\
\hline \multirow{4}{*}{$\begin{array}{l}\text { Persiapan } \\
\text { Tanam }\end{array}$} & Persiapan yang tidak sesuai SOP & E1 & 4,0 \\
\hline & Terhambatnya persiapan media tanam & E2 & 4,5 \\
\hline & Bibit yang siap tanam tertunda & E3 & 4,0 \\
\hline & Bibit terserang hama & E4 & 5,0 \\
\hline \multirow{4}{*}{ Penanaman } & Over produksi & E5 & 2,0 \\
\hline & Hasil tidak maksimal & E6 & 4,5 \\
\hline & Pertumbuhan tanaman lambat & E7 & 5,0 \\
\hline & Tanaman tidak tumbuh dengan baik & E8 & 4,0 \\
\hline \multirow{7}{*}{ Pemeliharaan } & Tanaman terserang hama trips & E9 & 5,75 \\
\hline & Tanaman terserang lalat penggorok daun & E10 & 4,0 \\
\hline & Tanaman terkena kutu daun & E11 & 4,0 \\
\hline & $\begin{array}{l}\text { Tanaman terkena penyakit seperti penyakit embun } \\
\text { tepung, bercak daun serkospora, dan penyakit yang } \\
\text { disebabkan oleh virus }\end{array}$ & E12 & 5,0 \\
\hline & Berkurangnya populasi & E13 & 4,0 \\
\hline & Tanaman overdosis pestisida & E14 & 4,0 \\
\hline & $\begin{array}{l}\text { Terjadi ketidakseimbangan jumlah kebutuhan hara } \\
\text { yang dibutuhkan tanaman }\end{array}$ & E15 & 4,0 \\
\hline \multirow{2}{*}{$\begin{array}{c}\text { Pengendalian } \\
\text { OPT }\end{array}$} & Organisme penganggu tanaman makin banyak & E16 & 4,5 \\
\hline & Kualitas rendah & E17 & 4,0 \\
\hline \multirow{4}{*}{$\begin{array}{l}\text { Panen dan } \\
\text { Pascapanen }\end{array}$} & Produktivitas rendah & E18 & 5,0 \\
\hline & Kualitas buah berkurang & E19 & 5,0 \\
\hline & Hasil panen tidak menentu & E20 & 4,5 \\
\hline & Ukuran tidak seragam & E21 & 5,0 \\
\hline \multirow[t]{2}{*}{ Pengemasan } & $\begin{array}{l}\text { Produk mengalami kerusakan fisik seperti penyusutan } \\
\text { buah, penyusutan berat }\end{array}$ & E22 & 5,6 \\
\hline & Buah mengalami kebusukan & E23 & 5,0 \\
\hline \multirow{2}{*}{ Pemasaran } & Fluktuasi harga & E24 & 2,0 \\
\hline & Komitmen dengan mitra & E25 & 2,0 \\
\hline
\end{tabular}


tanam paprika yaitu hama triphs sehingga menyebabkan penurunan atau gagal panen produksi paprika. Hama triphs menyerang tanaman paprika dengan cara menghisap cairan tanaman pada daun muda dan bunga. Gejala yang ditimbulkan dari serangan hama triphs ini terlihat pada permukaan bawah daun atau bunga. Ini terjadi karena dalam penangganan budidaya paprika masih terlihat kurang baik dan tidak sesuai dengan prosedur seperti yang terjadi dalam pemeliharaan, petani kadang-kadang memberikan dosis pestisida tidak sesuai dengan standar yang dianjurkan. Maka dalam jangka panjang akan menyebabkan hama menjadi resisten terhadap pestisida tersebut. Sehingga permasalahan ini menjadi sangat penting bagi petani karena berkaitan dengan produksi dan kualitas mutu yang dihasilkan, sehingga berdampak kepada pendapatan.

Berbagai kejadian risiko yang telah teridentifikasi tidak muncul begitu saja. Masingmasing kejadian risiko memiliki penyebab munculnya sendiri. Oleh karena itu, identifikasi sumber risiko atau source of risk pun perlu dilakukan. Diskusi dan wawancara yang telah dilakukan bersama petani membantu identifikasi sumber risiko yang terjadi dalam produksi paprika pada CV Cantigi Desa Cikandang Kabupaten Garut disajikan dalam Tabel 10.
Hasil perhitungan nilai ARP pada HOR tahap 1 produksi paprika menunjukkan "salah sasaran ketika pengendalian OPT" (A10) dan "iklim dan cuaca" (A2) merupakan sumber risiko dengan nilai ARP terbesar. Menurut Moekasan (2008), paprika merupakan tanaman semusim yang dapat tumbuh di dataran tinggi pada ketingian 700-1.500 m dpl dengan kelembaban udara sekitar $80 \%$. Tanaman paprika memerlukan temperatur $21{ }^{\circ} \mathrm{C}-27 \stackrel{\circ}{\mathrm{C}} \mathrm{C}$ pada siang hari dan $13 \stackrel{\circ}{\circ} \mathrm{C}$ $-16^{\circ} \mathrm{C}$ pada malam hari. Di Indonesia, tanaman ini cocok ditanam di dataran tinggi yang bersuhu 16 ${ }^{\circ} \mathrm{C}-25 \stackrel{\circ}{\circ} \mathrm{C}$ (Prihmantoro Heru dan Indriani Y.H., 2000). Iklim dan cuaca sangat berpengaruh pada produksi paprika, karena dapat menyebabkan kegagalan produksi. Apabila iklim dan cuaca tidak sesuai dengan syarat tumbuh paprika maka tanaman tidak dapat tumbuh dengan maksimal dan juga akan menyebabkan timbulnya hama maupun penyakit sehingga hasil panen pun tidak memuaskan. Pengendalian OPT juga merupakan hal yang penting ketika proses produksi karena jika terjadi salah sasaran maka organisme pengganggu tanaman tidak akan terkendali dan menyebabkan OPT pada tanaman semakin banyak sehingga dapat menyebabkan kualitas maupun kuantitas hasil produksi berkurang.

Dalam penanganan risiko, tidak semua sumber risiko mendapatkan sebuah penanganan. Hal ini disebabkan oleh beberapa faktor, yaitu dari

Tabel 10. Daftar Sumber Risiko Produksi Paprika

\begin{tabular}{clc}
\hline Kode & \multicolumn{1}{c}{ Sumber Risiko } & $\begin{array}{c}\text { Kemungkinan } \\
\text { Kejadian (0) }\end{array}$ \\
\hline A1 & Waktu persiapan lahan yang tidak tepat & 2,3 \\
A2 & Iklim dan cuaca & 3,25 \\
A3 & Alat dan bahan yang tidak sesuai dengan SOP & 2,0 \\
A4 & Waktu tanam yang tidak sesuai SOP & 2,0 \\
A5 & Penanaman yang tidak tepat & 2,8 \\
A6 & Kurangnya tenaga kerja & 2,0 \\
A7 & Waktu pengaplikasian nutrisi yang tidak tepat & 2,4 \\
A8 & Jumlah nutrisi yang tidak sesuai kebutuhan & 2,6 \\
A9 & Penyiraman yang tidak sesuai SOP & 2,0 \\
A10 & Salah sasaran ketika pengendalian OPT & 2,7 \\
A11 & Tenaga kerja yang tidak disiplin ketika bekerja & 2,0 \\
A12 & Waktu dan cara panen yang tidak tepat & 3,0 \\
A13 & Penangganan yang tidak baik setelah panen & 2,7 \\
A14 & Bahan pengemasan yang tidak tepat & 2,6 \\
A15 & Tidak ada kontrak tertulis dengan mitra & 2,0 \\
A16 & Jumlah permintaan tidak seimbang dengan jumlah penawaran & 2,5 \\
\hline
\end{tabular}


Tabel 11. Daftar Usulan Aksi Mitigasi Risiko

\begin{tabular}{cccl}
\hline Kode & Sumber Risiko Prioritas & Kode & \multicolumn{1}{c}{ Aksi Mitigasi } \\
\hline A2 & PA1 & $\begin{array}{l}\text { Memproduksi tanaman paprika } \\
\text { di bawah naungan seperti } \\
\text { screen house. }\end{array}$ \\
A10 & Salah sasaran ketika pengendalian OPT & PA3 & $\begin{array}{l}\text { Membuat kalender tanam. } \\
\text { Sebelum melakukan } \\
\text { pengendalian, maka OPT harus } \\
\text { diamati terlebih dahulu. }\end{array}$ \\
\hline
\end{tabular}

sisi biaya, tenaga, dan waktu yang terbatas. Oleh karena itu diperlukan pemilihan sumber risiko prioritas. Penentuan kategori sumber risiko prioritas dilakukan dengan menggunakan hukum pareto atau hukum 80:20. Aplikasi hukum pareto pada risiko adalah bahwa $80 \%$ kerugian disebabkan oleh hanya $20 \%$ risiko yang krusial (Kountur, 2008). Jika $20 \%$ risiko krusial tersebut dapat ditangani, maka perusahaan sudah dapat menghindari 80\% kerugian.

\section{Analisis House of Risk (HOR) Tahap 2 di Tingkat Petani}

Berdasarkan sumber risiko prioritas hasil perhitungan menggunakan tabel pareto maka ditentukan beberapa rencana aksi mitigasi untuk sumber prioritas tersebut. Untuk menemukan aksi mitigasi atau proactive action (PA) yang sesuai, dilakukan diskusi mendalam dengan petani paprika. Berikut yang dapat dilihat pada Tabel 11 terdapat beberapa aksi mitigasi yang direkomendasikan untuk petani berdasarkan sumber risiko prioritas.

Aksi mitigasi yang harus didahulukan penanganannya yaitu "memproduksi tanaman paprika di bawah naungan seperti screen house" (PA1) dan "membuat kalender tanam" (PA2). Hal ini dikarenakan tanaman paprika memerlukan suhu yang optimal untuk tumbuh. Tanaman paprika membutuhkan cahaya matahari yang cukup sepanjang hari agar dapat tumbuh serta berproduksi dengan baik dan tanaman paprika tidak bisa terkena curah hujan yang tinggi karena dapat menyebabkan tanaman mudah terserang penyakit maka dari itu tanaman paprika memerlukan naungan untuk berproduksi agar dapat menghasilkan kuantitas dan kualitas yang baik. Kalender tanam digunakan agar petani dapat memperkirakan waktu tanam yang tepat sesuai dengan iklim dan cuaca yang akan terjadi sehingga dapat meminimalisir risiko. Selanjutnya aksi mitigasi yang juga harus dilakukan juga yaitu sebelum melakukan pengendalian, maka OPT harus diamati terlebih dahulu (PA3), agar target OPT tidak salah sasaran Sehingga dapat mengatasi terserangnya hama dan penyakit.

\section{SIMPULAN DAN SARAN}

\section{SIMPULAN}

Berdasarkan hasil penelitian didapatkan simpulan sebagai berikut:

1. Setiap kegiatan produksi paprika pada CV Cantigi yang terdiri dari persiapan tanam, penanaman, pemeliharaan, pengendalian OPT, panen dan pascapanen, pengemasan, hingga pemasaran mengalami risiko.

2. Berdasarkan hasil identifikasi risiko, CV Cantigi mengalami 25 kejadian risiko dengan tingkat keparahan tertinggi yaitu tanaman terserang hama. Aksi mitigasi yang perlu dilakukan terlebih dahulu yaitu pengendalian OPT dengan tepat, melakukan budidaya paprika di bawah nauangan seperti pada screen house untuk menjaga suhu tetap optimal agar dapat mengurangi hama penyakit dan membuat kalender tanam untuk produksi paprika.

\section{SARAN}

Berdasarkan simpulan dan hasil penelitian yang telah diperoleh, saran yang dapat direkomendasikan yaitu :

1. Bagi petani paprika apabila ingin memproduksi paprika maka budidaya dilakukan di screen house agar bisa menjaga suhu tetap optimal, membuat kalender tanam agar dapat memperkirakan waktu tanam yang tepat, dan 
melakukan pengamatan terhadap tanaman sebelum melakukan pengendalian OPT agar tidak terjadi salah sasaran.

2. Sedangkan bagi penyuluh pertanian yaitu agar lebih berperan lagi dalam memberikan ilmu kepada petani seperti mengadakan sosisalisasi mengenai SOP budidaya tanaman paprika, penangganan hama penyakit yang tepat sehingga dapat mengatasi permasalahan yang terjadi pada budidaya paprika.

\section{DAFTAR PUSTAKA}

[BPS]Badan Pusat Statistik., 2014-2017. Produksi Tanaman Hortikultura (paprika). Tabel Dinamis.

[BPS].2017. Statistik Tanaman Sayuran dan BuahBuahan Semusim Indonesia. Badan Pusat Statistik. http://www.bps.go.id [10 Oktober 2018]

Dermawan, R. (2006). Pengambilan Keputusan Landasan Filsofis, Konsep, dan Aplikasi. Bandung: Penerbit Alfabeta.

Frantz, G., F. Parks, and H.C. Mellinger. 1995. Thrips Population Trends in Pepper in Southwest Florida. In B.L. Parker, M. Skinner and T. Lewis (Eds.). Thrips Biology and Management. Proceeding of a NATO Advance Research Workshop: The 1993 Int.Conf. Thysanoptera: Towards Understanding Thrips Management. Burlinton, Vermont. Sep. 28-30, 1993, NATO ASI Series. Vol. 276. Plenum Press, New York and London. p. 111-114.

Hanafi, Mamduh. 2006. Manajemen Risiko. Yogyakarta : Penerbit UPP STIM YKPN.

Hadinata, T. 2014. Standar Mutu Paprika: Potensi dan Kendala Bubidaya Tanaman Paprika di Rumah Plastik. Balitsa. Lembang-Bandung.

Harpenas, Asep \& R. Dermawan. 2010. Budidaya cabai unggul. Jakarta: Penerbit Penebar Swadaya.

Heru Prihmantoro dan Y.H.Indriani. 2000. Paprika Hidroponik dan Non Hidroponik. PT. Jakarta : Penerbit Penebar Swadaya.

Kountur, R. 2008. Mudah Memahami Manajemen Risiko Perusahaan. Jakarta: Penerbit PPM.
Moekasan, T.K. L. Prabaningrum, N. Gunadi. 2008. Budidaya Paprika di Dalam Rumah Kaca Berdasarkan Konsepsi Pengendalian Hama Terpadu (PHT). Balitsa. Lembang.

Mound, L.A. 2002. So many thrips-so few tospoviruses. In: R Marullo and L. Mound (Eds.) Thrips and Tospovirus. Proceeding 7th International symposium on Thysanoptera. Australian National Insect Collection, Cambera, ACT. p.15-18.

Murai, T. 2002. The pest and vector from the East: Thrips palmi In: R Marullo and L. Mound (Eds.) Thrips and Tospovirus. Proceeding 7th International symposium on Thysanoptera. Australian National Insect Collection, Cambera, ACT. p. 19-32.

Prabaningrum, L., S. Sastrosiswojo, dan T.K. Moekasan. 2002. Studi Pendasaran Usahatani Paprika di Jawa Barat Sebagai Suatu Landasan Pengembangan Pengendalian Hama Terpadu. Laporan Hasil Penelitian Balitsa Tahun 2002. 11 hlm.

Pujawan, I. and Geraldin, L.H., 2009. House of risk: a model for proactive supply chain risk management. Business Process Management Journal, 15(6), pp.953-967.

Savaringga, R. 2013. Strategi pengembangan usaha cabai paprika hidroponik di koperasi petani mitra Sukamaju kecamatan Cisarua kabupaten Bandung Barat. [Skripsi]. Bogor (ID); Institut Pertanian Bogor.

Sunjaya, P.I. 1970. Dasar-dasar Ekologi Serangga. Bagian Ilmu Hama Tanaman Pertanian, Institut Pertanian Bogor. 132 hlm. 